\title{
PÉTER ÉVA*
}

\section{AZ ERDÉLYI NÉPZENE MÁRKOS ALBERT ÉLETMÚVÉBEN}

Kulcsszavak: népzene mint ihletforrás, hangszeres vagy kórusfeldolgozás, polifó-
nia, homofónia, ellenpont

Márkos Albert zeneszerzői és zenepedagógusi munkássága egy célt szolgált: a magyar zeneművészet és zenekultúra felemelkedését. Jelen tanulmány röviden ismerteti Márkos életét és munkásságát, korabeli kritikák tükrében bemutatja azokat a mûveket, amelyekben érezhetô az erdélyi népzene hatása, majd válogatott vokális népdalfeldolgozások elemzésén keresztül rávilágít a zeneszerző alapvető kompozíciós elveire. ${ }^{1}$

\section{ID. MÁRKOS ALBERT (1914-1981) ÉLETE ÉS MUNKÁSSÁGA}

Székelykeresztúrról indult, felsőfokú tanulmányait Kolozsváron végezte a Zene- és Színművészeti Konzervatóriumban. 1932-ben hegedû- és zenetanári oklevelet nyert. Zeneszerzést Marţian Negreától tanult.

Munkássága kezdetén hangszertanárként tevékenykedett, ugyanakkor a Magyar Színház zenekarában hegedült. Fellépett hangszeres szólistaként, kamarazenészként és amatőr kórusokat is sikerrel irányított.

1946 után a Zenemúvészeti Főiskola professzora lett, zeneelmélet-szolfézst, akusztikát, módszertant, hangszerismeretet tanított. 1954-1958 között a Gheorghe Dima Zeneakadémia elméleti karának dékánja volt.

* PÉTer Éva (1965), PhD, tanár, a Babeș-Bolyai Tudományegyetem Református Tanárképző és Zenemúvészeti Kar előadótanára. E-mail: evapeter65@gmail.com.

1 Lásd a szerzőnek a témával foglalkozó átfogó korábbi munkáit: PÉTer Éva: Márkos Albert vokális népdalfeldolgozásai. Presa Universitară Clujeană, Kolozsvár, 2012; PÉTer Éva: Folk Song Arrangements in the Choral Works of Albert Márkos [Márkos Albert vokális népdalfeldolgozásai]. Studia Universitatis Babeș-Bolyai. Musica. LIV. 2009/2. 67-84. 
A kodályi elvek követőjeként a népdalalapú zenei oktatásért harcolt. ${ }^{2}$ Ennek elérése érdekében részt vállalt iskolai ének-zene tankönyvek ${ }^{3}$ összeállításában, a Mưvelódés című folyóiratban leckesorozatot vezetett Zeneiskola címmel, közremúködött a Metronom címû szolfézstár anyagának válogatásában.

Az amatőr kórusmozgalom egyik irányítójaként a zenei anyanyelv megismertetését, az erdélyi zenekultúra felemelését szolgálta. Az egyházzene területén az unitárius énekeskönyv és choral-könyv összeállításánál tevékenykedett.

Zeneszerzői tevékenysége sokszínú, több műfajban alkotott. Múvei között szerepelnek szimfonikus múvek, kamarazeneművek, balettzene, színpadi zene. A kórusirodalom múfaja megtalálható alkotótevékenységének szinte minden periódusában. A népzene hatása egész életmûvét áthatja.

1981. június 11-én, 77 éves korában hunyt el. László Ferenc kolozsvári muzikológus Márkos alkotásait „az erdélyi szimfonikus zenekincs legjavához” sorolta, ${ }^{4}$ alkotásaiban a „vitán felüli művészi minőséget” emelte ki. ${ }^{5}$ Benkő András zenetörténész Márkos műveinek újszerú hangvételét és a népdalokkal való szoros kapcsolatát hangsúlyozta: „Bár korunk modern nyelvén szól, az életadó forrásokról nem feledkezik meg". ${ }^{6}$

\section{A NÉPZENE HATÁSA MÁRKOS ALBERT MƯVÉSZETÉRE}

A népzene gyakran került a 20. századi magyar és erdélyi zeneszerzők figyelmének középpontjába. Mint tiszta forrásból, ebből merítettek ihletet saját múveik számára. Maga Márkos is azt vallotta egy interjúban: „Teleszívtam magam erdélyi magyar folklórral. Udvarhelyszéken gyüjtöttem. Kapcsolatba kerültem népzenészekkel, alaposan megismertem a magyar népdalt és a magyar népi zenélési módot. (...) Hogy egységes ötvözetet hozzak ki mindabból, amit magamba szívtam és ezt ugyanakkor

2 „Az iskolában a zenét legkönnyebben a népdallal lehet megszerettetni, mert ez áll közelebb a gyermek lelki világához. Zenei oktatásunk az elméleti ismereteket tartja elsődlegesnek, ahelyett, hogy a népdalok, a népek dalainak százaival ismertetné meg a tanulókat. Az elméletet a legszükségesebb ismeretekre kellene csökkenteni. A módszert illetően, a relatív szolmizáció a legcélravezetőbb.” Fábián Ernő: Zene és hivatás. Megyei Tükör, IV., 1971/ 498. 5 .

3 Id. Márkos Albert Guttman Mihállyal és Guttmanné Takács Gabriellával együttműködve tankönyvet szerkesztett az általános iskolai ének-zene oktatás számára.

4 LÁszló Ferenc: Búcsú sokak nevében. A Hét, XII., 1981/25.8.

5 LÁszLó Ferenc: Szerzői est helyett: emlékhangverseny. Utunk, XXXVII. 1982.

6 Benkő András: Búcsú Márkos Alberttől. Múvelődés, XXXIV. 1981/8-9. 22. 
az internacionális muzsika hangzásvilágának vívmányaival forrasszam össze. Ez az én legnagyobb törekvésem...”.

Más helyen is hangsúlyozza a népdal fontosságát: „... az a véleményem, hogy a legavantgardabb muzsikának is a kiindulása valamilyen formában a népdal kell hogy legyen. Természetesen nem idézet formában, hanem valahogyan magasabb szinten, hogy miképp, ez az egyes zeneszerzők dolga. Persze mindez elsősorban a hangszeres zenére vonatkozik...".

A zenei anyanyelv kérdéséról pedig erdélyi emberként vallott: „A hazai magyar zeneszerzőknek az erdélyi magyar folklórból kell kialakítaniuk anyanyelvüket. De ez nem azt jelenti, hogy a romániai magyar zeneszerző nem nyúlhat más nemzet folklórjához, mint ahogy azt Bartók is tette, mint tudjuk, román és más népek folklórját is feldolgozta, de zenei anyanyelve mégis tökéletesen magyar". ${ }^{9}$

A zeneszerző első alkotóperiódusában olyan zenekari múvek születtek, amelyek közvetlenül népi ihletésűek: Erdélyi szvit (1951), Székely táncok szimfonikus szvit (1951), Román népi tánc (1951), Bihari vendégek szvit (1956). Ez utóbbit a Marosvásárhelyi Állami Székely Együttes kérésére írta. Az Egy népi tánc zenéje (1956) címú művet az Orvosi és Gyógyszerészeti Karon múködő népi együttes számára komponálta. Zenekarra és énekkarra írt népdalszvitek: Hargitai régi táncok, Udvarhelyszéki emlékek (1957), Korondi bál (1969).

A Székely táncokat bemutató hangversenyre készült műsorfüzet kiemeli a mú ritmusának szinkópás, élénk jellegét, a harmonizálását pedig Bartók és Kodály népdalfeldolgozásaival rokonítja: „... egy szinkópás ritmusú élénk népi tánc, tele lendülettel és a csárdás jókedvével. A mủ megharmonizálása abban a realista szellemben készült, melyben a nagy magyar zeneszerzők, Bartók Béla és Kodály Zoltán feldolgozta a magyar népdalok és néptáncok gyönyörü dallamát. A székely népdalokhoz és néptáncokhoz közeledve Márkos Albert zeneszerző hozzájárult az erdélyi magyar zeneirodalom gazdagításához." 10

Szintén a népzene szellemében fogant Márkos első szimfóniája: Per prospera ad libertatem (1960). A háromtételes mú értékelésekor Lakatos István zenetörténész kiemelte annak arányos szerkezetét, karakteres dallamait, változatos ritmusát, valamint Márkos biztos tudását, amellyel uralja kora kompozíciós technikáját: „Ez a szimfónia ihletett, komoly tudású zeneszerző munkája (...) három tételének arányos szerkesztése formailag a régi úton halad. Határozott arcélü dallamok, változatos ritmusok, jól hangzó polifonikus szerkesztés érzik e szimfónián, amelyben a szerző a mai zene-

7 Pintér Lajos: Márkos Albert. Előre, XVIII. 1970. 8.

8 Simon Dezső: Márkos Albert, párbeszéd az alkotóval. Utunk, XXVII. 1972/48. 6.

9 Pintér Lajos: Márkos Albert. Előre, XVIII. 1970.

10 Săptămâna muzicii românești. Program de sală. Ateneul Român, București, 22-30 septembrie 1951. (a szerző fordítása). 
szerző-technika és összhangvilág mesterségbeli fogásait biztos kézzel alkalmazza”. ${ }^{11}$ A sokszínű erdélyi zene dallamvilágának finom mixtúráját emeli ki egy későbbi írásában Lakatos: „Márkos Albert szimfóniájában szerencsésen ötvözi össze a sokszínű erdélyi népi zenét. A hagyományos zenei kifejezés és formavilág felhasználásával, korunk zenéjének technikájával, olyan munkát alkotott, amely méltán érdemelte ki a közönség megelégedését". ${ }^{12}$

Vonószenekari múve, a Kodály emlékére komponált Prelúdium és fúga vonószenekarra. „In memoriam Kodály Zoltán”, 1975-ben készült el. Alapja a Jőnek, jőnek... szövegkezdetứ népdal dallama, melyet ugyanabban az évben dolgozott fel női karra. A múvet a kolozsvári Zenelíceum zenekara mutatta be 1976-ban.

A versenyművek közül elsőként a Hegedüverseny készült el, 1958-ban. A témák forrására vonatkozóan, valamint a zenemű technikai megvalósításával kapcsolatosan, Lakatos István zenetörténész a következőket írta: „Bemutatott hegedúversenyében Márkos Albert olyan új hangot üt meg, amelynek a jellege egyéni és éppen ez a varázsa. Különös dallamok, el nem csépelt fordulatok, egészséges ritmusképletek jelzik Márkos új alkotási időszakát. (...) Márkos nem formabontó, hanem a régi hegedűversenyek útján jár, kifejező eszközei sem járnak új utakon, muzsikájában mégis sajátosat mond a régi, újromantikus technika kereteiben. Muzsikája őszinte, kellemes, frissítő hatású. Látszik, hogy maga is jól ismeri a hegedút és ki tudja használni e hangszer lehetőségeit”. ${ }^{13}$

A Simfonia concertante (Versenyszimfónia) fúvósötösre, két vonószenekarra és ütőhangszerekre 1964-ben készült el. A mú tételei: Preludium, Scherzo, Pastorale, Rondo. Benkő András a Múvelódés folyóirat hasábjain így jellemzi a művet: „Simfonie concertantejában az egykor hűvös, rideg tizenkétfokúság, barátságos népdal-dodekafóniává szelídül”. ${ }^{14}$ Lakatos István a múfaji meghatározásról, a feldolgozott dallamról, a feldolgozás technikájáról a következőket jegyzi kritikájában: „Az új Simfonia concertante, amely szórakoztató jellegü, és így rokonságban áll a Divertimentókkal, a Szvittekkel, lényegében egy kromatikus dallamra épült, melynek jellege a tételek változásával átalakul (...) Technikában a bartóki többszólamú szerkesztés eszközeit váltogatja." Legsikerültebbnek a kritikus a Scherzo-tételt tartja, kiemeli emellett a Pastorale címú tétel képszerúségét és a záró részben megjelenő, karikatúrajellegű korált és fúgát: „Igen élvezetes a hargitai tájakat idéző Pastorale című zenei kép (...) valamint az ötletes utolsó tétel, a záró részben felbukkanó korállal és a csúfondáros fú-

11 Lakatos István: Az elsô szimfónia. Igazság, 1963. október 26.

12 LakATos István: Zenei élet. Igazság, 1964. január 29.

13 LA KATos István: Kolozsvári szerző alkotása a Filharmonikusok müsorán. Igazság, 1961. május 20.

14 Benkő András: Búcsú Márkos Alberttól. Müvelődés, XXXIV. 1981/8-9. 22. 
gával, amelyben a mindenáron fontoskodó többszólamú technikát idéző újabb zeneszerzők elé tár görbe tükröt, saját maga kontrapunktikus írásmódját is kigúnyolva". ${ }^{15}$

A kamarazene múfaja is jelen van Márkos életművében. A táncban címú, hegedûre és zongorára komponált mủ alapját tiszta folklór alkotja. Lassú bevezető után virtuóz rész következik, majd egy siratójellegư, kromatikában bővelkedő középrész után a mú vidám jellegü, fokozatosan gyorsuló népi táncot idéző zenei anyaggal zár. ${ }^{16}$

1968-ban Márkos színpadi zenét komponál Tamási Áron Énekes madár címú színdarabjához. Búzás Pál kétzongorás átiratot készített a müből. Ennek bemutatója kapcsán Kulcsár Gabriella zenekritikus kiemeli Márkos vonzódását a népzenéhez: „... köztudott, hogy Márkos Albert zeneszerzőként, pedagógusként, emberként a népdal szerelmese volt. A múben az énekszerü betétek a népdalt, a népi humort idézik. A néhány pillanatra eluralkodó sejtelmességet markáns paraszttánc szakítja félbe, az idillikus pillanatnak a határozott giusto-férfitánc vet véget”. ${ }^{17}$

\section{A NÉPDALOK FELDOLGOZÁSI MÓDJA MÁRKOS KÓRUSMÜVEIBEN}

Márkos érdeklődése a múkedvelő kórusmozgalom iránt már zeneszerzői munkássága kezdetén megmutatkozott. Bekapcsolódott Jagamas János munkacsoportjába, és tevékenyen részt vállalt a kalotaszegi népdalok gyưjtésében, feldolgozásában és azok betanításában. Márkos Albert vezette a körösfői, Jagamas János a mérai, Szalay Miklós a mákófalvi, Búzás Pál a bikali, Vermesy Péter a vistai, Orbán György a györgyfalvi énekkart. Nemes cél vezérelte őket: élővé tenni a népi kultúrát. ${ }^{18} \mathrm{~A}$ múkedvelő együttesek kórusfesztiválon léptek fel Bánffyhunyadon, Tordaszentlászlón, Aranyosegerbegyen. Ezek az együttesek különböző összetételűek voltak, ezért a feldolgozások között találunk két- vagy háromszólamú egynemú karra írt darabot is, de legjellemzőbb a vegyeskari feldolgozás.

A vizsgált anyagban van egy dallam, amelyet Márkos két különböző változatban dolgozott fel. A Kimosom a zsebkendômet... kezdetú népdalnak kétszólamú egynemú,

15 Lakatos István: Kolozsvári szerzó müvének bemutatója. Igazság, 1964. december 23.

16 Lásd bővebben LÁszló Ferenc: Márkos Albert: A táncban. Népzenei „természet” és zeneszerzői lelemény egy jellemdarabban. In: Zenetudományi írások 1998. Szerk.: LÁszLó Ferenc. Kriterion-Magyar Tudományos Akadémia Zenetudományi Intézet, Bukarest-Budapest, 1999. 132-145.; LÁszlóf Fy Réka: „Nem éltem hiába”. Márkos Albert hegedú-zongora darabjáról. In: Hausmann KóRódy Alice (szerk.): Erdélyiség a magyar zeneszerzoók múveiben. Partiumi Keresztény Egyetem, Nagyvárad, 2018. 100-112. (Szerk. megj.)

17 Kulcsár Gabriella: A táncban. Szabadság, XV., 2003/127.

18 Lásd részletesen Fábián Ernő: Zene és hivatás címú írásában a Márkos Alberttel folytatott interjú szövegét. Megyei Tükör, IV/498, 1971. XI. 28. 
illetve négyszólamú vegyeskari változata van. A dallam a kisambitusú újabb réteghez tartozik. Hangsora (1. kottapélda) a plagális réteget is érintő kvartpilléres moll pentachord.

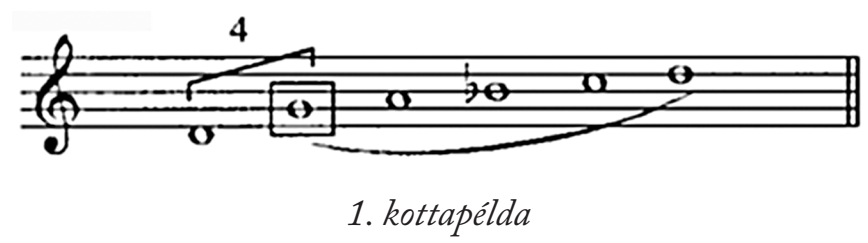

A strofikus feldolgozású kétszólamú változat hangneme g-moll. A népdal dallama a szopránban található. Az alt szólam negyed hangértékủ dallammozgással kíséri azt, a sorok végén található szünet alatt pedig nyolcadmozgással tartja fenn az egyenletes lüktetést. Az ismétlődő első sor kísérô szólamának indító motívuma azonos a népdal első dallamsora záró motívumának rákfordításával. A harmadik dallamsor szólamainak ellenmozgása után a negyedik dallamsor unisono résszel zárul.

A négyszólamú változat variációs formájú. Az első versszak feldolgozása a női szólamokra épít. A mű elején a szopránban megjelenő dallamhoz csupán sor végén társul az alt szólam egy-egy imitált motívummal. A harmadik dallamsor három hangból álló, emelkedő irányú kezdő motívumát két időegységnyi távolságra imitálja az alt szólam. A homofon szerkezetú záró rész az előbb tárgyalt kétszólamú, strofikus feldolgozás azonos sorával megegyező.

A négyszólamú feldolgozásban a teljes második rész kísérete hosszú, pedálszerúen kitartott hangokból áll (2. kottapélda): a basszusban $g$ alaphang, a tenorban ennek felső oktávja, melyet a „sej” indulatszóra énekelnek. Az alt szólam fél- és negyedértékekben ellenpontozza a nyolcadokban mozgó dallamot. 

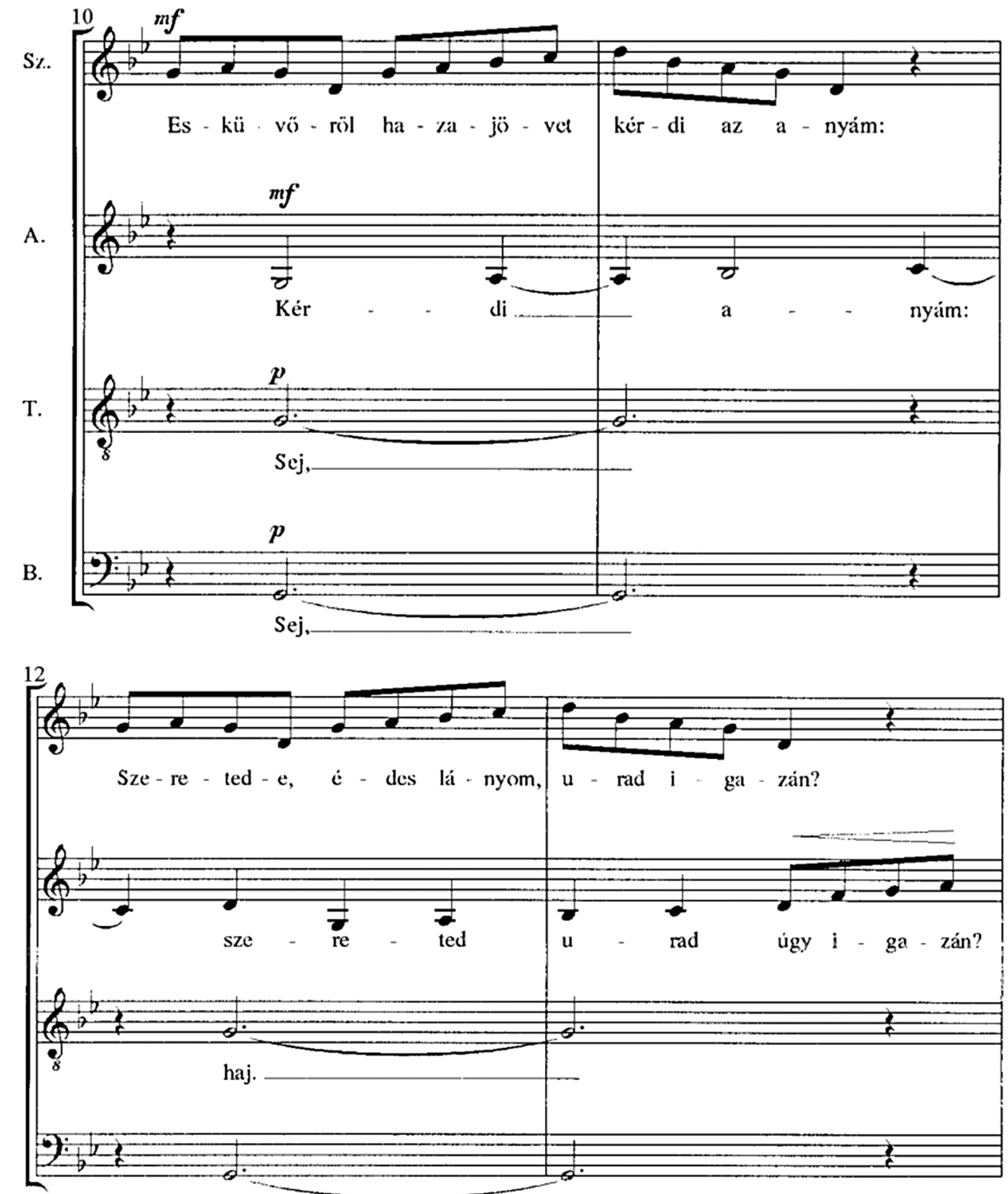

haj.

\section{2. kottapélda}

A harmadik versszakban, a feldolgozás záró részében, lecsökken a szólamok száma, így unisonóban énekel a szoprán az alttal, a tenor a basszussal (3. kottapélda). A férfi szólamok oktáv hangtávolságban, egy időegységnyi távolságra imitálják a női 
szólamokat, majd két ütem után felcserélődnek a szerepek, és a férfi szólamok indítanak, a női szólamok imitálnak.
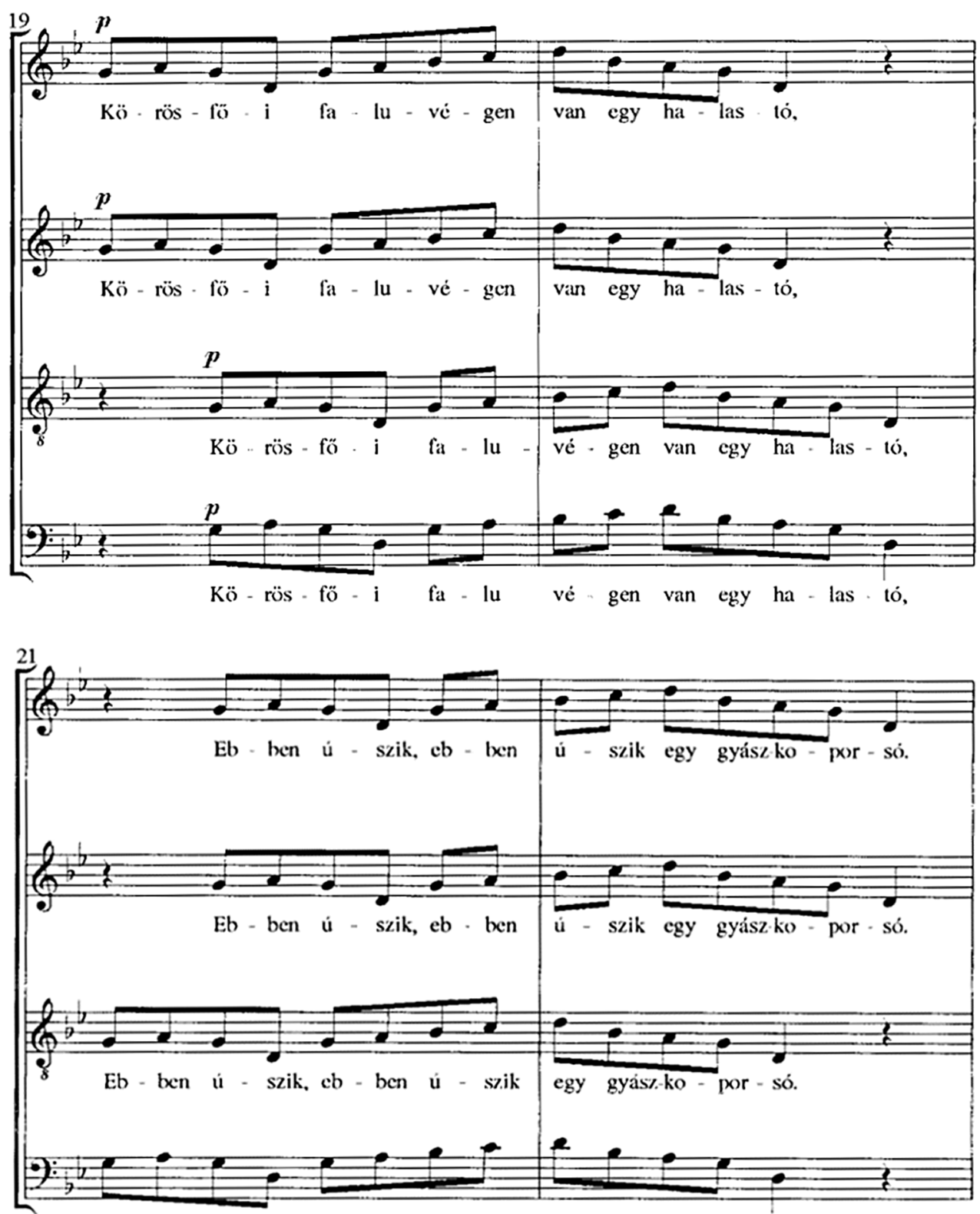

Eb ben ú - szik, eb - ben ú - szik egy gyász-ko - por - só.

\section{3. kottapélda}


A záró részben kvintekből és szekundokból szerkesztett, különböző megfordítású akkordok szólalnak meg (4. kottapélda), melyek hatodik fokú szextakkordra, a secunda voltában I. fokra oldódnak.

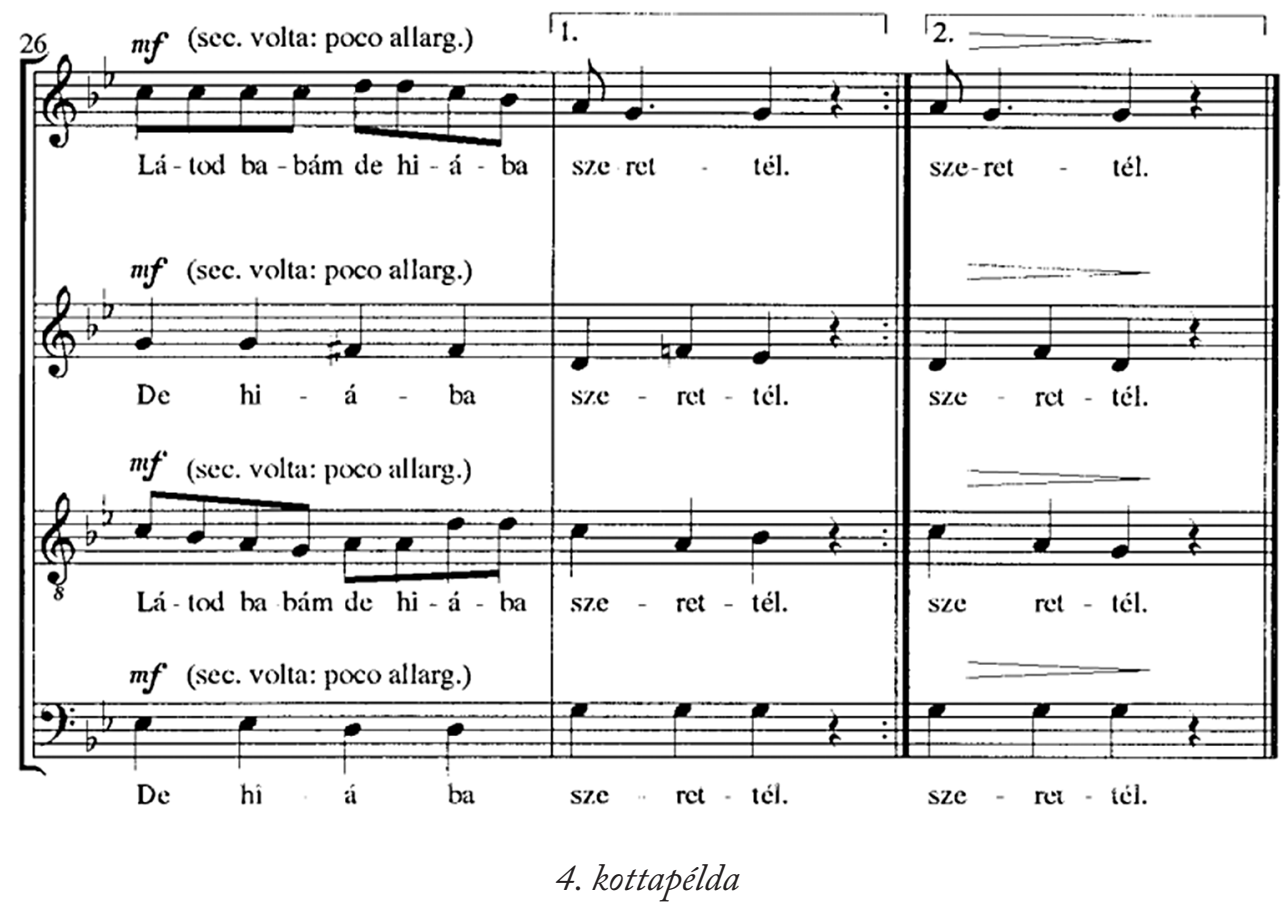

Második példánk a Jônek, jönek, hogy vigyenek... kezdetű népdal ötsoros, úgynevezett jajnóta. Ötödik dallamsorát ,ja-ja-ja” szövegpótló szótagokkal éneklik. Régi stílusú, recitáló, pszalmodizáló dallam. A pentaton alaphangkészlet felső rétegében (5. kottapélda) a moll jelleget a hangsor kis szextje emeli ki.

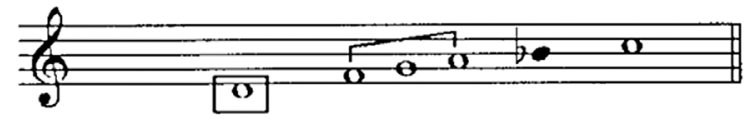

\section{5. kottapélda}

A variációs feldolgozás első versszakában a dallamot a szoprán, mezzoszoprán és alt szólam unisonóban mutatja be. A szöveg tartalma indokolja ezt, hisz a dal menyasszonybúcsúzó, amelyet a nők szoktak énekelni csoportosan. A második versszakban (6. kottapélda) a dallamhoz kétszólamú, terc-, kvart-, szextmixtúrákban megjelenő kíséret társul. A pontozott félértékekben mozgó kíséret, 6/4-es ütemben, két 
időegységgel későbben indul, mint a dallam; harmonikusan előlegezés, metrikailag szinkópalánc benyomását kelti, amely tulajdonképpen egy ritmuskompenzálás, általa minden negyedlüktetésen mozgás érzékelhető.
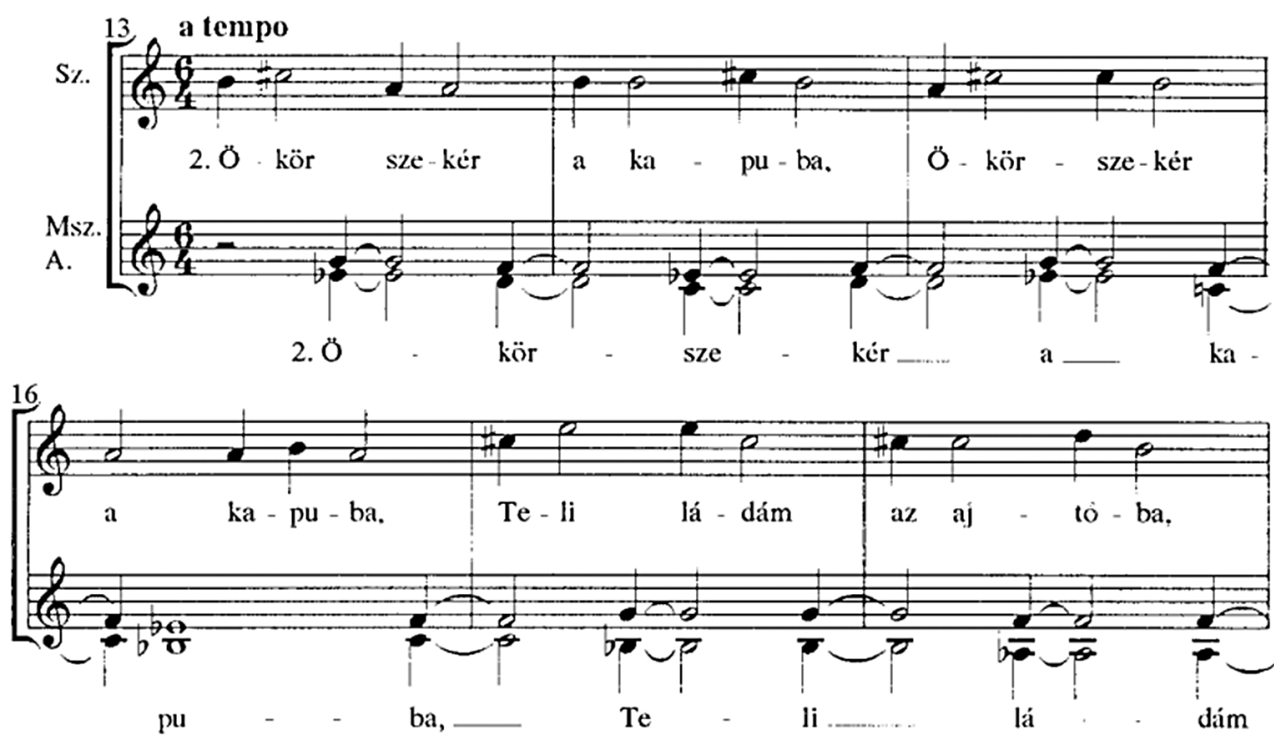

6. kottapélda

A harmadik versszakban (7. kottapélda), a négyütemnyi, kétszólamú imitatív részben megjelenik az előzőekben említett metrikai eltolódás a szólamok között. 

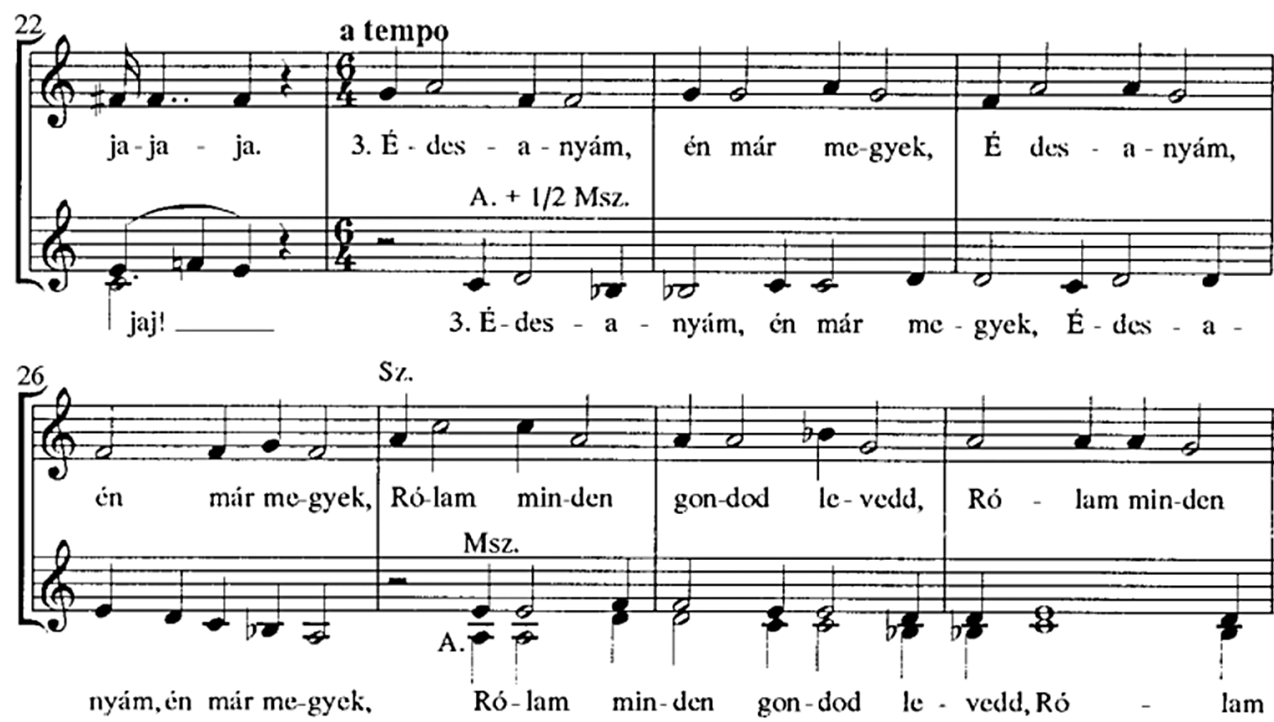

\section{7. kottapélda}

A kíséret a dallam alsó kvintjén reális imitációval indul, majd a pentaton mag kiemelésével (8. kottapélda) modális elhajlás történik, $g$-dórba.

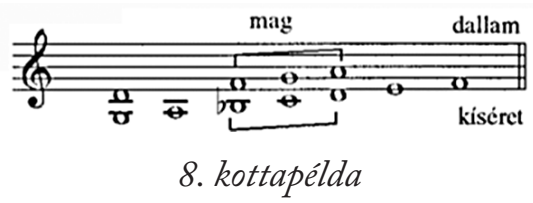

A variációk egy részében változik a hangnem a különböző strófák feldolgozásánál. Jelen esetben a második és negyedik versszakban a dallam nagy terccel fennebb, fisz hangra kerül. A mű modális ábrája a következőképpen alakul: $d$-fisz-d-fisz. A két kísérő szólamban használt hanganyag diatonikus, $g$-fríg móduszt alkot. A második versszak utolsó két ütemében két új elem jelenik meg: fisz és $e$ (9. kottapélda), így a részleges kromatika teljes kromatikává alakul.

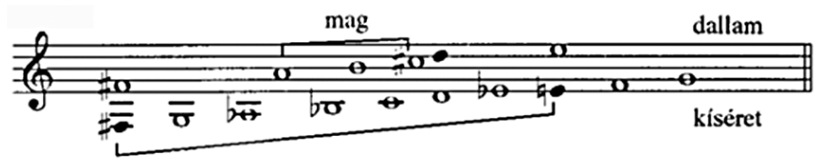

9. kottapélda 
Harmadik példának az új stílusú dallamok közül a Tatárhágón van egy magas eper$f a$ címút választottam bemutatásra. Jellegzetes architektonikus szerkezetü: a szélső $\mathrm{A}$ sorok azonosak, a közbelső B sorok közül a második variált (ABBvA). A közbelső B sorok kvint fölötti dallamjárása következtében a dallamvonal boltíves.

A dallam alaphangneme pentaton pien hangokkal (10. kottapélda), váltakozó eol/dór jelleggel.

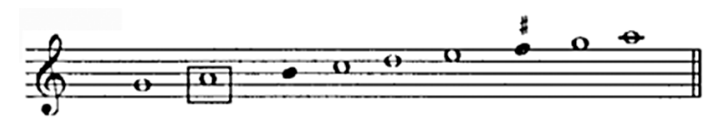

10. kottapélda

A feldolgozásban a dallam $e$ hangon szerepel (11. kottapélda).

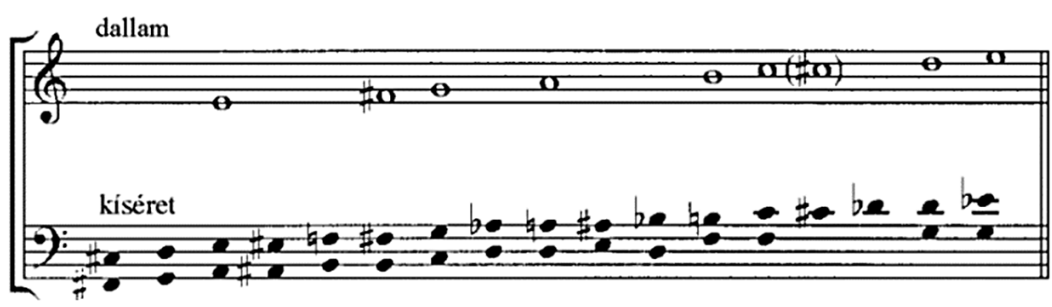

\section{1. kottapélda}

A mű variációs feldolgozás, hangneme módosul a feldolgozás során. A változása domináns hangnembe történik ( $e-h-e)$, amely elsőfokú rokon hangnem.

Az első strófa feldolgozásának különlegessége, hogy kvintmixtúrában halad a dallam kísérete. Ezekben a mixtúrákban mintegy ostinato-szerűen ismétlődik egy négy időegységnyi forgó motívum, kígyózó vonalban (12. kottapélda). A feldolgozásban változik az ütem. A kísérő szólamok együtemes bevezetője után egy-egy dallamsor ütemeinek beosztása: 3/4+3/4+4/4. Ezért az említett motívum metrikus szempontból eltolódik. A dallamvonal változása folyamán a motívum elmozdul a sorok kadenciájának megfelelően: $e$-re, illetve a második sorban $h$-ra, fisz-re (két ereszkedő kvart), minden megszakítás nélkül. 

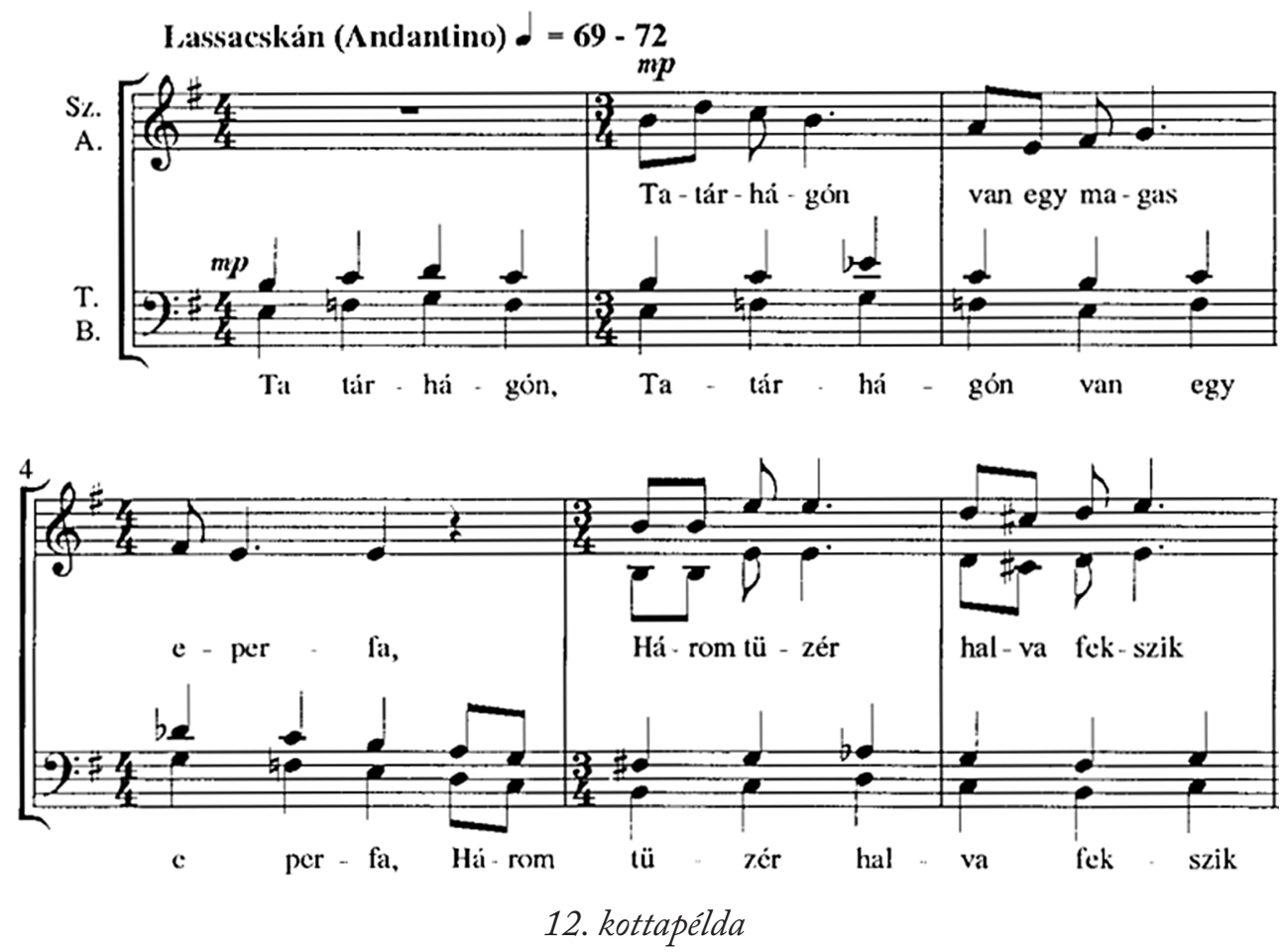

A mú második versszakában imitációs rész hallható (13. kottapélda). Az egy időegységnyi távolságra induló imitáció első alkalommal megőrzi az eredeti dallam hangközeit, a következő dallamsornál viszont a kvartugrás helyett kvintugrás következik. 

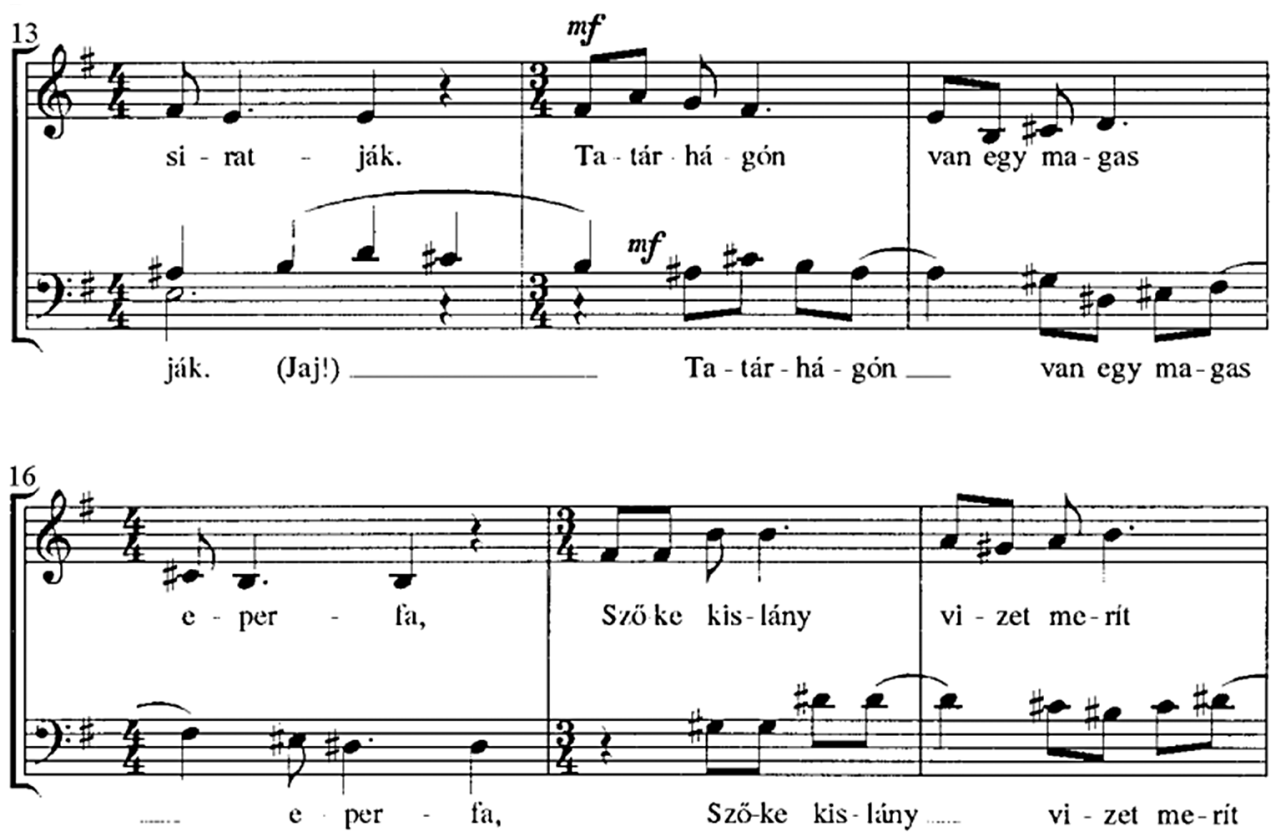

\section{3. kottapélda}

A hangközök szigorú imitációja tekintetében tehát egyetlen kivétel látható: a 17. ütemben (13. kottapélda), a népdal második versszakának második sorában a dallam V. fokról VIII. fokra lép: $h$-mollban fisz- $h$, tiszta kvart, míg a második szólam válaszában disz-mollban IV. fokról VIII. fokra, tiszta kvintet lép, tehát a válasz tonális.

Az imitáló szólam a módosított hangok révén (14. kottapélda) úgy gazdagítja a dallam diatonikus szerkezetét, hogy teljes kromatika alakul ki.

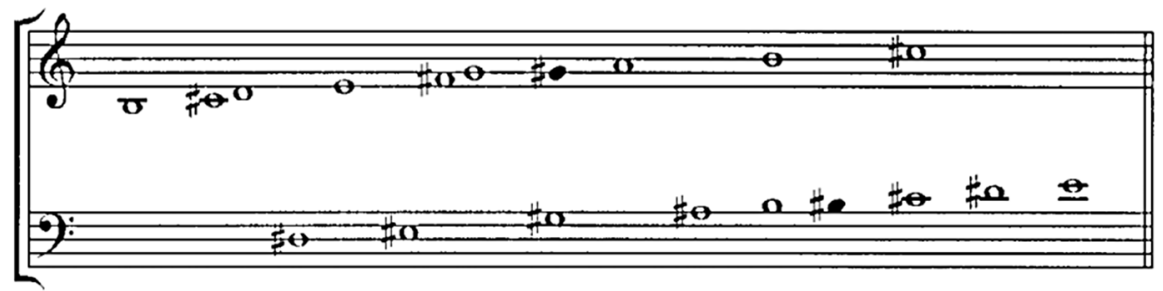

\section{4. kottapélda}

Az utolsó versszakban a szólamok vezetése lineáris, de felcsillannak homofon pillanatok. Kvart- (15.a, 15.b kottapélda) és szekundakkordok (15.c, 15.d, 15.e kottapélda) különböző megfordításai jelennek meg. Ezek mellett, nagy szekundokból és 
kis tercekből felépített, félhang nélküli pentaton szeletekből alkotott akkordok találhatók.

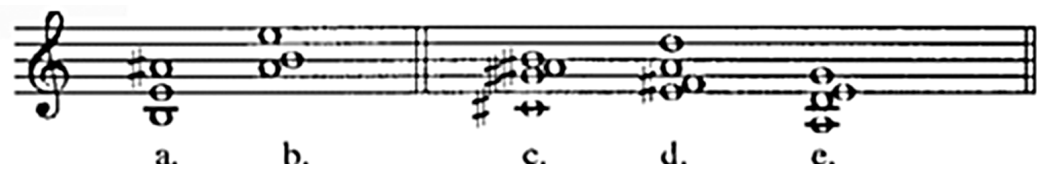

15. kottapélda

Negyedik példa a Kalákának Rugonfalvára címú szvit. A múben régi stílusú dallamokat dolgoz fel a szerző. Az első dallam, A citrusfa levelestôl, ágastól... kezdősorú esetében a hangsor fríg (16. kottapélda), a felemelt harmadik fok miatt bőmásodos színezetet nyer. A hétfokú hangsor ellenére ezt a dallamot a pentaton réteg mellé is lehet sorolni. Dallamjárása és szerkezete szerint a kvintismétlés nyomait hordozza, amit a 45 VII 1 kadenciarend támaszt alá. Emellett végig a pentaton fokok alkotják a dallammenet pillérhangjait.

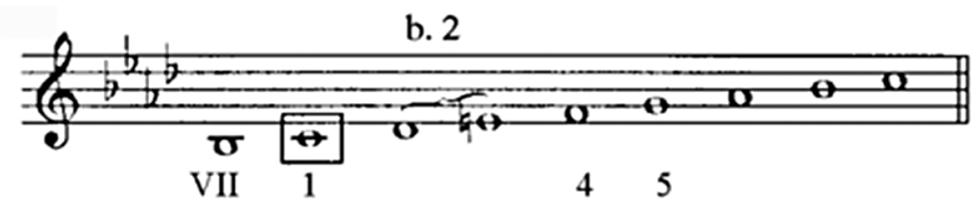

16. kottapélda

A ciklus második dallama, az Édös anyám, gyújts gyertyára... szövegkezdetű népdal dúr hexachord (17. kottapélda) hangsorban mozog.

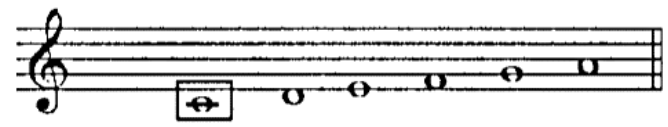

17. kottapélda

A ciklus harmadik darabja, az Érik a szóló, hajlik az ága... ereszkedő kvintváltó dallama.

A ciklus felépítése összetett. A variációs feldolgozás egy-egy részében külön szerepelnek a női, külön a férfi szólamok, néha unisonóban énekelnek, máskor két szólamban (férfiak, nők), és mintegy kiszélesítve az együttest, megjelenik a négyszólamú vegyeskar is. 
A mú szerkezete: a)b)a)b)c). Az a) részek tempója Andante, a b) részeké Più lento, míg a záró c) rész Allegretto. Az a) dallam mindkét alkalommal $c$-frígben jelenik meg (bőmásoddal), csak a feldolgozás módja változik. A b) dallam előbb $C$-dúrban, második alkalommal ennek elsőfokú rokon hangnemében: $F$-dúrban található. A b) részek feldolgozási módja különböző: az első az ellenpont technikáját alkalmazza, a második pedig az imitációt. A c-dúrban lévő záró c) dallam ellenpontozott.

A ciklus első dallama, az A citrusfa levelestöl, ágastól... kezdetủ népdalt kétféleképpen dolgozza fel a múben. Első alkalommal szigorú, unisono imitációban (18. kottapélda), melyben a szólamok két időegységnyi távolságra követik egymást;

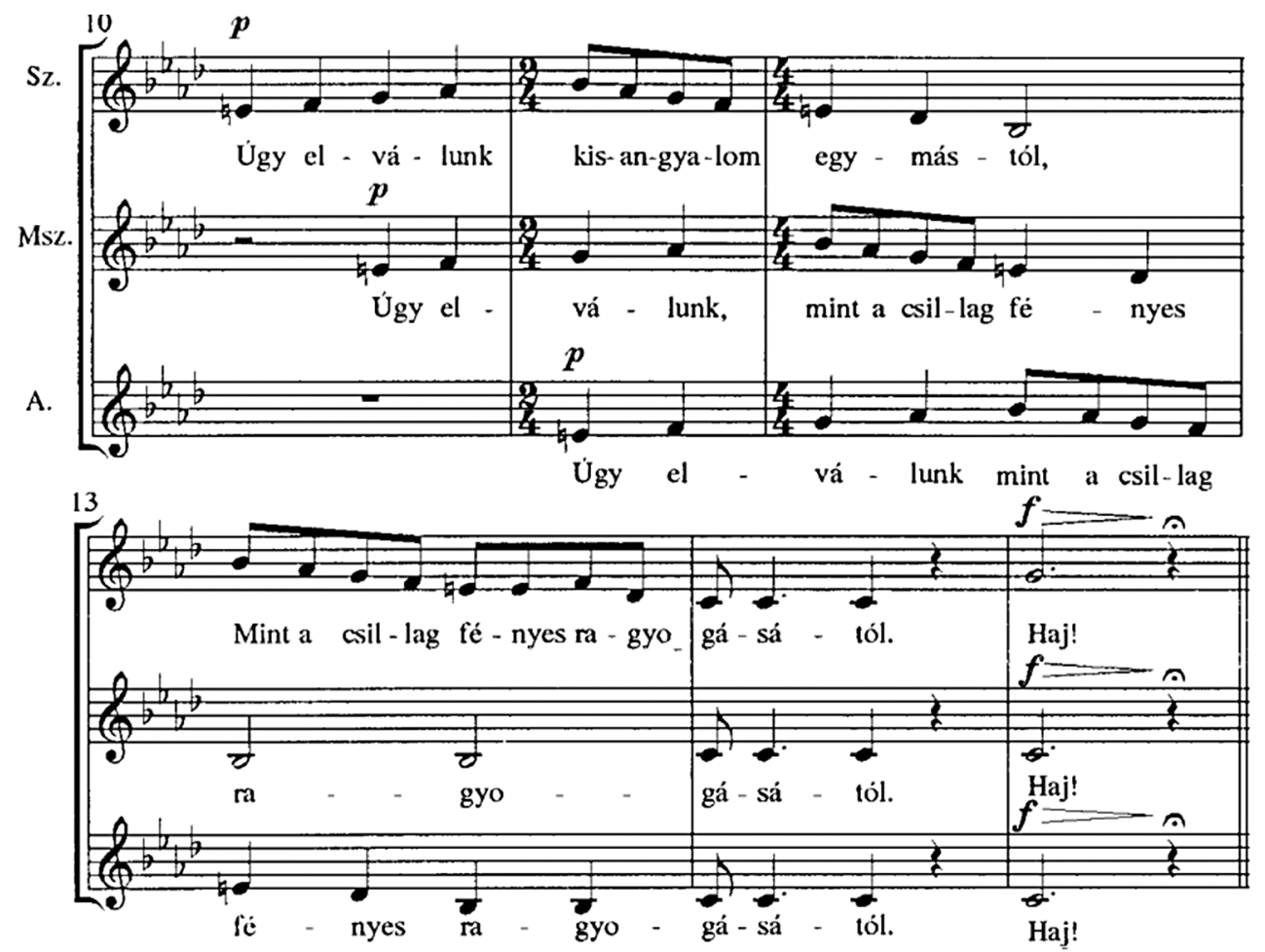

18. kottapélda

második alkalommal szabad imitációban: csak a kezdő motívumot tartja meg a zeneszerző (19. kottapélda), majd változatként ellentétes irányú, emelkedő dallammenettel érkezik a zárlatba. 


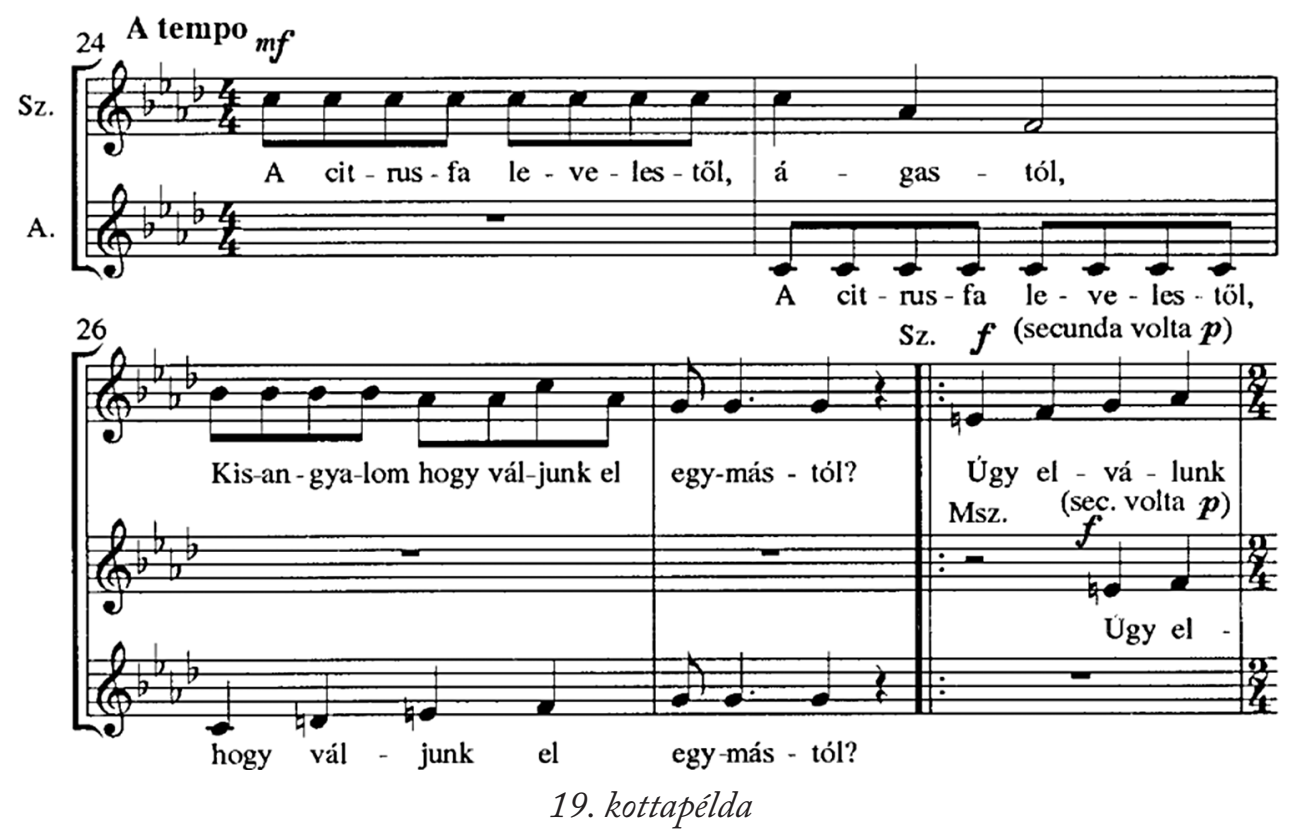

A népdalok feldolgozási módját tekintve megállapíthatjuk, hogy Márkos polifon és homofon szerkesztési technikát egyaránt alkalmaz. Ritkán jelenik meg tisztán egyik vagy másik feldolgozási mód, sokkal jellemzőbb ezek kombinációja. Előfordul, hogy a népdal különböző versszakait, vagy a ciklusba foglalt népdalfeldolgozások részeit más-más módon dolgozza fel. A részek összeillesztése viszont törésmentes.

A szigorú imitáció prím, oktáv, kvint és ereszkedő kis szext hangtávolságra történik Márkos múveiben. Láthatóan kedvelt a sztrettó. A polifonikus feldolgozás másik fajtája, a szabad imitáció a feldolgozott népdal motívumaira, dallamfordulataira alapoz. A hangközlépések nincsenek szigorúan betartva, csak a dallam körvonala marad állandó.

Id. Márkos Albert kórusművei a szólamok függetlenségére vagy legalább a szólamok lineáris vezetésének elsődlegességére épülnek. De ebben a polifóniában függőleges harmonizálási elv is létezik. Vannak feldolgozási részek, melyekben a szólamok együttes mozgásával akkordfüzések keletkeznek. Esetenként megtalálható múveiben a kíséretes monódia is. Ez a kíséret többféleképpen jelent meg: terc-, szextmixtúrák; kvintmixtúrák, melyekben ostinatóként ismétlődik egy forgó vagy boltíves motívum; vannak esetek, melyekben a kíséret helyett hosszan tartott, úgynevezett pedálhangok, orgonapont jelenik meg egy vagy két szólamban, melyekhez hozzáadódik az ellenpontozó, harmadik szólam.

Márkos a népdalok feldolgozásában a művészi igényességet kiválóan társítja az egyszerűséggel. Mưveinek nehézségi szintje a kezdő és haladó, iskolai és amatőr kó- 
rusok technikai képességeihez alkalmazkodik. Hivatásának tekintette nemcsak a szakemberek oktatását, hanem a zeneszeretők széles körének nevelését is.

\section{TRANSYLVANIAN FOLK MUSIC IN THE WORK OF ALBERT MÁRKOS, THE COMPOSER}

\section{Keywords: folklore as a source of inspiration, instrumental or choral processing, polyphony, homophony, counterpoint}

The study presents a short glance upon the life and work of composer Albert Márkos (1914, Cristuru Secuiesc - 1981, Cluj-Napoca), followed by the analysis of four of his choral works, more precisely, the folk songs' arrangements for choirs. The analysis focuses on aspects regarding the sources of inspirations, the origin of the folk songs, their arrangement as well as the various composition techniques used.

\section{MUZICA POPULARĂ ÎN CREATIA COMPOZITORULUI ALBERT MÁRKOS}

Cuvinte-cheie: folclor ca sursă de inspirație, prelucrări instrumentale sau corale, polifonie, omofonie, contrapunct

Prima parte a lucrării cuprinde date privind viața și activitatea compozitorului, pedagogului clujean Albert Márkos (1914, Cristuru Secuiesc - 1981, Cluj-Napoca). În partea a doua sunt prezentate lucrările inspirate din folclorul din Transilvania. În final sunt analizate patru prelucrări corale de melodii populare. Analiza propriu-zisă a prelucrărilor de melodii populare cuprinde aspecte cu privire la sursa de inspirație (muzica populară), la originea melodiilor, la modalităţile de prelucrare și la tehnica componistică utilizată. 